\title{
Checklist of the Heleomyzidae, Neriidae and Oestridae (Insecta, Diptera) in the State of Mato Grosso do Sul, Brazil
}

\author{
Julia Calhau', Alessandre Pereira-Colavite², Tatiana Sepúlveda², \\ Claudio José Barros de Carvalho², Priscylla Moll de Arruda', Silvio Shigueo Nihei ${ }^{3}$, \\ Cecília Kosmann ${ }^{4}$, Cristiane V. A. Pujol-Luz ${ }^{5}$ \& José Roberto Pujol-Luz ${ }^{4}$
}

\footnotetext{
1. Universidade Federal da Grande Dourados, Faculdade de Ciências Biológicas e Ambientais, Cx. Postal 533, Cidade Universitária, 79804-970, Dourados, MS.Brazil.juliacalhau@gmail.com)

2. Laboratório de Biodiversidade e Biogeografia: Diptera, Depto de Zoologia, Universidade Federal do Paraná, Caixa Postal 19020, 81.531-980, Curitiba, PR, Brazil.

3. Depto de Zoologia, Instituto de Biociências, Universidade de São Paulo, Cidade Universitária, 05508-900, São Paulo, SP, Brazil.

4.Universidade de Brasília, Instituto de Ciências Biológicas, Depto de Zoologia, 70.910-900, Brasília, DF, Brazil.

5. Coordenação Geral do Programa Nacional de Controle da Dengue, Ministério da Saúde, SCS Quadra 04, Bloco "A", Edifício Principal, $1^{\circ}$ andar, sala s/n,

Unidade VI, 70304-000 Brasília, DF, Brazil.(cristiane.luz@saude.gov.br)
}

Received 21 November 2016

Accepted 6 February 2017

DOI: $10.1590 / 1678-4766 e 2017143$

ABSTRACT. We provide a checklist of flies of the families Heleomyzidae, Neriidae, and Oestridae in the State of Mato Grosso do Sul, Brazil. Heleomyzidae are represented in Brazil by 13 species, and only Neorhinotora aristalis (Fischer) is recorded to the State of Mato Grosso do Sul. The two reported species of Neriidae, Longina abdominalis Wiedemann and Nerius pilifer Fabricius, are among the 15 species now known in Brazil. The Oestridae family is represented by two species distributed in two genera: Dermatobia hominis (Linnaeus Jr.) and Cuterebra rufiventris Macquart.

KEYWORDS. Biodiversity, catalogue, taxonomy, Biota-MS Program.

RESUMO. Lista de Heleomyzidae, Neriidae e Oestridae (Insecta, Diptera) no Estado do Mato Grosso do Sul, Brazil. É apresentada uma checklist de espécies de Heleomyzidae, Neriidae e Oestridae do Estado de Mato Grosso do Sul, Brasil. Heleomyzidae, família representada no Brasil por 13 espécies, possui registro apenas de Neorhinotora aristalis (Fischer) para o Estado de Mato Grosso do Sul. Duas espécies de Neriidae, Longina abdominalis Wiedemann e Nerius pilifer Fabricius, das 15 com registro de ocorrência para o Brasil, foram identificadas. A família Oestridae é representada no Estado por duas espécies distribuídas em dois gêneros: Dermatobia hominis (Linnaeus Jr.) e Cuterebra rufiventris Macquart.

PALAVRAS-CHAVE. Biodiversidade, catálogo, taxonomia, Programa Biota-MS

This article is part of a series of checklists of the State of Mato Grosso do Sul (Brazil) and comprises data of three groups of cyclorrhaphan flies: the families Heleomyzidae, Neriidae, and Oestridae (Insecta, Diptera). Those three groups are very poorly known in the State of Mato Grosso do Sul, with very few species recorded. For this reason, we provide here data concerning those three groups in a single work.

Heleomyzidae are a cosmopolitan group of flies, being most commonly found in temperate forests, and in in mountainous and cooler areas in the tropics (SINCLAIR \& McAlpine, 1995). The group is composed of 22 tribes (McAlpine, 1985), of which Rhinotorini and Diaciini are the only tribes recorded from Brazil (PAPAVERo, 1967; GILL, 1968; MCALPINE, 1985). Rhinotorini are represented in Brazil by three genera: Neorhinotora Lopes, with four species, Rhinotoroides Lopes, with a single species and Rhinotora Schiner, with six species (PAPAVERo, 1967). The tribe Diaciini, in turn, is represented in Brazil by only two species, Diacia diadema (Wiedemann, 1830) and Dichromya sanguiniceps
(Wiedemann, 1830). In Brazil, the Heleomyzidae are very rarely observed in the field, and rarely collected.

Adults of Rhinotorini adults can be trapped with "MacPhail" traps, using fruit or cane syrup as bait, although the collection efficiency is quite low (Almeida \& AleRochA, 2008). Eventually, Rhinotorini are also collected with Malaise traps. Any other information on the natural history of Brazilian Heleomyzidae is unavailable.

The Neriidae comprise a small family of Acalyptrate flies, with about 110 species in 19 genera. These flies are found in all biogeographic regions, the majority of which are circumtropical. Of the tropical species, 42 are from the New World, with 15 in Brazil. In Brazil, these flies have been most studied in states of Rio de Janeiro and São Paulo.

The Neriidae are best known in the Neotropical Region by the studies of three researchers. ENDERLEIN (1922) contributed by naming nine species in nine genera and defining the family with 19 species in 11 genera. HeNNIG (1937) revalidated Enderlein's study and named an additional 
nine species, providing a list of 39 species in nine genera. Finally, ACzÉL (1949, 1951, 1961) produced several studies including a catalog, systematic revision and a revision of American species. AczéL (1951) raises the group to the status of family and described seven species and two new genera. The most recent information about the Neriidae in the Neotropical Region is found in the catalog by STEYSKAL (1968), which includes the 15 species known from Brazil. Only two species in the family are known from the State of Mato Grosso do Sul, but to date, no study has focused on the fauna of the west-central region of Brazil.

The family Oestridae is widely distributed in the tropical region and comprises species characterized by the obligate parasitic habit of mammals (GUIMARÃES \& PAPAVERO, 1999; PAPE, 2010), causing myiasis (GUIMARÃES \& PAPAVERO, 1999). This defines them as one of the most important dipterous group of medical and veterinary interest (GUIMARÃES \& PAPAVERO, 1999). The adults, rarely seen or collected (CATTS, 1982), are large and robust flies, their coloration varying from black to yellowish, with some metallic species (PAPE, 2010). Their mouthparts are reduced or totally absent at adult stage and their life are brief, dedicated to reproduction, host seeking, and oviposition (CATTS, 1982). Approximately 190 species are distributed worldwide, and 37 of them are found in the Neotropical Region (Guimarães \& PAPAVERo, 1999). The group is divided into four subfamilies, Hypodermatinae, Gasterophilinae, Oestrinae and Cuterebrinae (PAPE, 2001), the latter being distributed exclusively in the Neotropical Region (GUIMARÃES, 1967a).

Larvae of Dermatobia hominis (Linnaeus Jr.) have been reported in 94\% of the Brazilian municipalities (Guimarães \& PaPAVERO, 1999). In the State of Mato Grosso do Sul, the following Dipteran families were identified as D. hominis egg vectors: Calliphoridae, Sarcophagidae, Muscidae, Fanniidae, and Tabanidae (Gomes et al., 1998). Additionally, Guimarães \& PAPAVEro (1999) list also Culicidae, Simuliidae, Anthomyiidae, and ticks of the family Ixodidae.

In the present paper, we provide a checklist of the species of the families Heleomyzidae, Neriidae, and Oestridae occurring in the State of Mato Grosso do Sul.

\section{MATERIAL AND METHODS}

The following sources were used for this checklist to determine species that occur or are likely to occur in Mato Grosso do Sul: Wiedemann (1830), Schiner (1868), Lopes (1934, 1935, 1936), PAPAVERo (1967), Gill (1968), McAlpine (1985), and Almeida \& Ale-Rocha (2008) (for Heleomyzidae), ENDERLEIN (1922), HeNNIG (1937), ACZÉL (1961), and BuCK \& MARSHALl (2004) (for Neriidae) and Guimarães (1967a,b,c), Guimarães \& Papavero (1966), Gomes et al. (1998), Papavero (1977), Colwell et al. (2006), and Papavero \& Guimarães (2008) (for Oestridae). Additionally, for Neriidae, we also examined material in the Coleção Entomológica 'Padre Jesus Santiago Moure'
(DZUP), in the Departamento de Zoologia of the Universidade Federal do Paraná (UFPR).

\section{RESULTS AND DISCUSSION}

\section{List of species in the State of Mato Grosso do Sul}

\section{HELEOMYZIDAE, RHINOTORINI Neorhinotora aristalis (Fisher, 1932)}

Localities: Fazenda Murtinho, Três Lagoas. Geographic distribution: Brazil (Amazonas, Mato Grosso do Sul, Minas Gerais, Rio de Janeiro, São Paulo). Type-locality: "Fazenda Murtinho" [Holotype male deposited at Museu de Zoologia da Universidade de São Paulo, MZSP]. Ref.: LoPES (1935), Papavero (1967), Gill (1968), McAlpine (1985), Almeida \& Ale-Rocha (2008).

The following species of Rhinotorini are known from adjacent Brazilian states, and might be found in the State of Mato Grosso do Sul: Neorhinotora mutica (Schiner, 1868); Neorhinotora fonsecai (Lopes, 1934); Rhinotora diversipennis Lopes, 1936; Rhinotora lopesi Guimaraes \& Papavero, 1966; Rhinotora pluricellata Schiner, 1868; Rhinotora salesopolitana Guimarães \& Papavero, 1966; Rhinotora spiloptera Guimarães \& Papavero, 1966; Rhinotora travassosi Lopes, 1934; Rhinotoroides bifurcata Lopes, 1934.

\section{NERIIDAE, NERIINAE Longina abdominalis Wiedemann, 1830}

Localities: Maracaju. Type-locality: "Brasilien”. Geographic distribution: Brazil (Mato Grosso, Bahia, Minas Gerais, Espírito Santo, Mato Grosso do Sul, Rio de Janeiro to Rio Grande do Sul), Paraguay, Argentina (Misiones).

Ref.: BuCK \& MARSHALl (2004).

\section{Nerius pilifer Fabricius, 1805}

Localities: Corumbá, Dois Irmãos do Buriti (Palmeiras), Miranda, and Salobra. Type-locality: “America meridionali”. Geographic distribution: Mexico (Tabasco), Haiti, Costa Rica, Panama, Colombia, Venezuela, Guyana, Surinam, Brazil (Amazonas, Pará, Acre, Tocantins, Rondônia, Bahia, Mato Grosso, Goiás, Minas Gerais, Mato Grosso do Sul, São Paulo), Ecuador, Peru, Bolivia, Paraguai, Argentina (Tucumán).

Ref.: HenNig (1937), ACZÉL (1961), DZUP.

The following species of Neriidae are known from near Mato Grosso do Sul and are almost certainly found in the State: Cerantichir peruana (Hennig, 1937), distribution: Mato Grosso (east); Glyphidops (Glyphidops) filosus Fabricius, 1805, distribution: Mato Grosso (west); Glyphidops (Oncopsia) limbatus Enderlein, 1922, distribution: São Paulo (west); Nerius terebratus Enderlein, 1922, distribution: Paraguay (north-central); Nerius robustus Enderlein, 1922, distribution: Bolivia (east). 


\section{OESTRIDAE, CUTEREBRINAE Dermatobia hominis (Linnaeus Jr., 1781)}

Localities: Campo Grande, in Cerrado macroregion. Type-locality: "Peru". Geographic distribution: From Mexico to northern Argentina, except Chile. Ref.: Gomes et al. (1996, 2002).

\section{Cuterebra rufiventris Macquart, 1843}

Localities: Maracaju, in Cerrado macroregion. Type-locality: Brazil, Pará. Geographic distribution: Brazil (Amazonas, Pará, Mato Grosso do Sul, Rio de Janeiro, Santa Catarina), Ecuador, Peru. Ref.: Guimarães \& Papavero (1999); Colwell et al. (2006).

Main research groups on Heleomyzidae, Neriidae, and Oestridae. Heleomyzidae: in Brazil, the only specialists in the family are Drs. Nelson Papavero, Julia Calhau, and Rosaly Ale Rocha. Among the most prominent taxonomists currently working with the group in other parts of the world, Dr David McAlpine (Australian Museum, Australia) and Dr Andrzej Woznika (Wroclaw University of Environmental and Life Sciences, Poland) can be cited.

Neriidae: the only group studying taxonomy and systematics of the family Neriidae is the Laboratório de Sistemática e Biogeografia: Diptera, in the Departamento de Zoologia of the Universidade Federal do Paraná (UFPR), with Alessandre Pereira-Colavite and Tatiana Sepúlveda.

Oestridae: according to Directory of South American Dipterists (CARVALHO, 2009), there are no taxonomists or systematists of Oestridae nowadays. However, there is at least one research group concerned to study the systematics of Oestridae, which is the Laboratory headed by Dr. José Roberto Pujol-Luz (Departamento de Zoologia, Instituto de Ciências Biológicas, Universidade de Brasília).

Main collections. Heleomyzidae: the Heleomyzidae are very rare in entomological collections in Brazil, being the Museu de Zoologia da Universidade de São Paulo (MZSP) and the Museu Nacional do Rio de Janeiro (MNRJ) the most representative museums in terms of number of specimens, including type-specimens. The Instituto Nacional de Pesquisas da Amazônia (INPA), in turn, has the largest collection of specimens of Heleomyzidae collected in Brazilian Amazon.

Neriidae: the main collections of the Diptera in Brazil comprise over 2,000 specimens in the Neriidae (and the number continues to grow; CARvalHo et al., 2002). The collections include the DZUP, with 200 specimens, the Instituto Nacional de Pesquisas da Amazônia (INPA) has 581 specimens, the Museu Nacional of the Universidade Federal do Rio de Janeiro (MNRJ) has 28 specimens, the Museu Paranaense 'Emílio Goeldi' of Pará (MPEG) has 285 specimens and finally, the Museu de Zoologia of the Universidade de São Paulo (MZUSP) has 920 specimens. Oestridae: species of Oestridae are extremely low represented in Brazilian collections. According to CARVALHO et al. (2002), the following institutions possess adult pinned specimens of
Oestridae: Museu Nacional, Universidade Federal do Rio de Janeiro, Rio de Janeiro-RJ (MNRJ), with 61 specimens of 18 species; Museu de Zoologia da Universidade de São Paulo, São Paulo-SP (MZSP), with 32 specimens; and Departamento de Zoologia da Universidade Federal do Paraná, Curitiba-PR (DZUP), with four specimens of two species. There are also 35 specimens of four species of this family deposited in the entomological collection of the Universidade de Brasília (J. R. Pujol-Luz, pers. comm.).

Main knowledge gaps in the study of Heleomyzidae, Neriidae, and Oestridae in Brazil. As several families of Acalyptratae Diptera, Heleomyzidae are considered very problematic from the standpoint of taxonomy, with wide variation in its classification throughout its history. There is a large gap in systematics knowledge of Heleomyzidae. Phylogenetic studies with the group are unavailable, and therefore the monophyly of the family and their tribes have not been tested. Knowledge about species distribution in Brazil is also quite precarious, since most records of occurrence are concentrated in well-sampled areas like Southeast Brazil. Bionomic and behavioral studies with the Brazilian species are nonexistent, and constitute a major challenge due to the rarity of specimens in the field.

Like heleomyzids, the Neriidae of Mato Grosso do Sul are poorly known for two main reasons. First, the lack of collecting studies, in contrast to the adjacent and better studies areas that include the Amazon to the north, southeastern and southern Brazil, Paraguay, and Argentina to the south, and Peru and Bolivia to the west. Second, species in this family are difficult to identify and thus it is likely that zoological collections have specimens that remain unidentified.

Due to the parasitic habit of oestrids, the majority of the studies concerning this group are focused on medical and veterinary studies (e.g. MoYA-BorJa et al., 1993; GoMES et al., 1996), or on the findings of hosts carrying oestrids eggs (e.g. BRUM et al., 1996; Gomes et al., 2002, 1998; MARCHI et al., 2012; MARINHO et al., 2003). Taxonomic studies for the Neotropical fauna were mainly published by Dr José Henrique Guimarães and Dr Nelson Papavero (GUIMARÃEs \& CARRERA, 1941; GUIMARÃES, 1966, 1967a,b,c, 1971, 1984 1989; Guimarães \& PAPAVERo, 1966, 1999; PAPAVERo \& GuimarÃes, 2008). Regarding the systematics, the major publication is the Oestridae phylogeny by PAPE (2001) recovering the phylogenetic relationships among the world genera of Oestridae.

Besides the major interest in Oestridae by veterinary and medical research, there is also the difficulty in collecting these flies. The maggots can only be collected in their hosts, which requires very distinct equipment and methods of collection, in comparison to free-living dipterous collection. The adults have an extremely short life, being rarely seen by specialists in the field or collected by their traps. For all these reasons, a larger collection effort covering different locations, at different periods of the year, is needed in order to better sample the diversity of the family and provide material for further systematic studies of the group. 
Prospects for study for the next 10 years. Future study of the families over the next 10 years is strongly linked to the development of the SISBIOTA project for the westerncentral region of Brazil, especially in the Pantanal of Mato Grosso do Sul.

Acknowledgments. The involvement of the authors was not the same in the whole study: JCA was responsible for the Heleomyzidae data; APC, TS and CJBC prepared all the Neriidae data; while PMA, SSN, CK, CVAPL and JRPL were responsible for the Oestridae data. We thank Fundação de Apoio ao Desenvolvimento do Ensino, Ciências e Tecnologia do Estado de Mato Grosso do Sul (Fundect) and Superintendência de Ciências e Tecnologia do Estado de Mato Grosso do Sul (Sucitec/MS) for the invitation to participate in this special issue of Iheringia, Série Zoologia and financial support for publication. This study is part of the SISBIOTA project with financial support from Conselho Nacional de Desenvolvimento Científico e Tecnológico (CNPq) (Proc. \#563256/2010-9) and Fundação de Amparo a Pesquisa do Estado de São Paulo (FAPESP) (Proc. \#2010/52314-0). JCA thanks FAPESP for the PhD scholarship (Proc. No. 2009/07803-6). APC, TS and CJBC thank the Conselho Nacional de Desenvolvimento Científico e Tecnológico $(\mathrm{CNPq})$ for the research grants (APC proc. \#140754/2011-3; TS proc. \#130370/2011-8; CJBC proc. \#304713/2011-2). We would like to thank James J. Roper for translating the Neriidae part from the original Portuguese. PMA thanks FAPESP for the Master's scholarship (Proc. \#2012/9256-5). CK and CVAPL thank the following financial supports: CNPq, FAPDF, Coordenação de Aperfeiçoamento de Pessoal de Nível Superior (CAPES), and Financiadora de Estudos e Projetos (FINEP).

\section{REFERENCES}

ACZÉL, M. L. 1949. Catálogo de la Familia de las «Tylidae» (Calobatidae + Micropezidae + Neriidae, Diptera) en la Region Neotropical. Acta Zoológica Lilloana 8:309-389.

ACZÉL, M. L. 1951. Morfologia externa y division sistemática de las «Tanypezidiformes» com sinopsis de las espécies argentinas de «Tylidae» («Micropezidae») y «Neriidae» (Dipt.). Acta Zoológica Lilloana 11:483-589.

ACZÉL, M. L. 1961. A Revision of American Neriidae (Diptera, Acaliptratae). Studia Entomologica 4:257-346.

Almeida, J. C. \& Ale-Rocha, R. 2008. Taxonomic review of Neorhinotora Lopes 1934 (Diptera, Heleomyzidae). Zootaxa 1936:40-58.

Brum, J. G. W.; Vianna, E. E. S.; Gentilini, F. \& Pinto, L. S. 1996. Fannia punctipennis (Diptera: Fanniidae), vetor de ovos de Dermatobia hominis (Oestridae: Cuterebridae) em Pelotas, RS. Revista Brasileira de Parasitologia Veterinária 5(1):59-60.

Buck, M. \& Marshall, S. A. 2004. A review of the genus Longina Wiedemann, with descriptions of two new species (Diptera, Neriidae). Studia Dipterologica 11(1):23-32.

Carvalho, C. J. B. 2009. Directory of South American Dipterists. Available at: $<$ http://zoo.bio.ufpr.br/diptera/south/index.html $>$.

Carvalho, C. J. B. DE; Couri, M. S.; Toma, R.; Rafael, J. A.; Harada, A. Y.; Bonatto, S. R.; Henriques, A. L. \& Gastal, H. A. De O. 2002. Principais coleções brasileiras de Diptera: histórico e situação atual, $37-$ 52. In: Costa, C.; Vanin, S. A.; Lobo, J. M. \& Melic, A. eds. Proyecto de Red Iberoamericana de Biogeografia y Entomologia Sistemática (PrIBES). Monografías Tercer Milenio, vol. 2. Zaragoza SEA. 329p.

CatTs, E. P. 1982. Biology of the New World bot flies: Cuterebridae. Annual Review of Entomology 27:313-338.

Colwell, D. D.; Hall, M. J. R. \& Scholl, P. J. 2006. The Oestrid Flies: Biology, host-parasite relationships, impact and management. Cambridge, CAB International. 376p.

Enderlein, G. 1922. Klassifikation der Micropeziden. Archiv für Naturgeschichte (A) 88:140-229.

Gill, G. D. 1968. Family Heleomyzidae. In: PAPAvero, N. ed. A Catalogue of Diptera of the Americas South of the United States. São Paulo, Departamento de Zoologia, Secretaria da Agricultura, p. 1-13.

Gomes, A.; Honer, M. R. \& Silva, R. I. 1996. Intensidade parasitária de larvas de Dermatobia hominis (L. Jr. 1781) (Diptera: Cuterebridae) em bovinos de diferentes raças criadas extensivamente na região de cerrado em Mato Grosso do Sul. Revista Brasileira de Parasitologia Veterinária 5:103-106.
Gomes, A.; Honer, M. R.; Koller, W. W. \& DA Silva, R. L. 1998. Egg carriers of Dermatobia hominis (L. Jr. 1781) (Diptera: Cuteribridae [Cuterebridae]) in a Brazilian savanna area, Mato Grosso do Sul State, Brazil. Revista Brasileira de Parasitologia Veterinária 7(1):37-40.

Gomes, P. R.; Koller, W. W.; Gomes, A.; Carvalho, C. J. B. \& Zorzatto, J. R. 2002. Dípteros faniídeos vetores de ovos de Dermatobia hominis em Campo Grande, Mato Grosso do Sul. Pesquisa Veterinária Brasileira 22(3):114-118.

Guimarães, J. H. 1966. Nota sobre os hábitos dos machos de Dermatobia hominis (Linnaeus, Jr.) (Diptera, Cuterebridae). Papéis Avulsos do Departamento de Zoologia 18(25):277-279.

Guimarães, J. H. 1967a. Family Cuterebridae. In: Papavero, N. ed. A Catalogue of Diptera of the Americas South of the United States. São Paulo, Departamento de Zoologia, Secretaria da Agricultura, p. 1-11.

Guimarães, J. H. 1967b. Family Gasterophilidae. In: Papavero, N. ed. A Catalogue of Diptera of the Americas South of the United States. São Paulo, Departamento de Zoologia, Secretaria da Agricultura, p. 1-4.

Guimarães, J. H. 1967c. Family Oestridae. In: PAPAVERo, N. ed. A Catalogue of Diptera of the Americas South of the United States. São Paulo, Departamento de Zoologia, Secretaria da Agricultura, p. 1-4.

GuimarÃes, J. H. 1971. Note on the hosts of Neotropical Cuterebrini (Diptera, Cuterebridae) with new records from Brazil. Papéis Avulsos de Zoologia 25(10):89-94.

GUIMARÃES, J. H. 1984. New genera and species of Neotropical Cuterebridae (Diptera, Cyclorrhapha). Revista Brasileira de Entomologia 28(1):2327.

Guimarẽes, J. H. 1989. Revision of the Subfamily Rogenhoferinae StatNov (Diptera, Cuterebridae). Memórias do Instituto Oswaldo Cruz 84(4):255-261.

Guimarẽes, J. H. \& Papavero, N. 1966. A tentative annotated bibliography of Dermatobia hominis (Linnaeus, Jr.) (Diptera, Cuterebridae). Arquivos de Zoologia do Estado de São Paulo 14(4):223-294.

Guimarães, J. H. 1999. Myiasis in Man and Animals in the Neotropical Region; Bibliographic Database. São Paulo, Plêiade. 308p.

Guimarães, J. H.; Papavero, N. \& Prado, A. P. 1983. As mí́ases na região Neotropical (Identificação, biologia, bibliografia). Revista Brasileira de Zoologia 1:239-416.

Guimarães, L. R. \& CARrera, M. 1941. Contribuição ao conhecimento dos cuterebrídeos do Brasil. Arquivos de Zoologia do Estado de São Paulo 3:1-12.

Hennig, W. 1937. Übersicht über die Arten der Neriiden und über die Zoogeographie dieser Acalyptraten-Gruppe (Diptera). Stettiner Entomologische Zeitung 98:240-280.

Lopes, H. S. 1934. Nota prévia sobre alguns Rhopalomeridae (Dipt.). Revista de Entomologia 4:517.

Lopes, H. S. 1935. A sub-família Rhinotorinae Williston (Dipt.Rhopalomeridae). Arquivos do Instituto de Biologia Vegetal 2(1):1926.

LOPES, H. S. 1936. Sôbre duas espécies brasileiras de Rhinotora Schiner (Dipt. Rhopalomeridae). Revista de Entomologia 6(1):106-109.

Marchi, M. J.; Pereira, P. A.; Menezes, R. M. T. \& Tubaki, R. M. 2012. New records of mosquitoes carrying Dermatobia hominis eggs in the State of São Paulo, Southeastern Brazil. Journal of the American Mosquito Control Association 28(2):116-118.

Marinho, C. R.; Barbosa, L. S.; Azevedo, A. C. G.; Queiroz, M. M. C.; Valgode, M. A. \& Coelho, V. M. A. 2003. Hemilucilia segmentaria (Fabricius, 1805) (Diptera: Calliphoridae) as new biological vector of eggs of Dermatobia hominis (Linnaeus Jr., 1781) (Diptera: Oestridae) in Reserva Biológica do Tinguá, Rio de Janeiro, Brazil. Memórias do Instituto Oswaldo Cruz 98(7):937-938.

McAlpine, D. K. 1985. The Australian genera of Heleomyzidae (Diptera: Schizophora) and a reclassification of the family into tribes. Records of the Australian Museum 36(5):203-251.

Moya-Borja, G. E.; Muniz, R. A.; Sanavria, A.; Gonçalves, L. C. B. \& Rew, R. S. 1993. Therapeutic and persistent efficacy of doramectin against Dermatobia hominis in cattle. Veterinary Parasitology 49:8593.

Papavero, N. 1967. Family Rhinotoridae. In: Papavero, N. ed. A Catalogue of Diptera of the Americas South of the United States. São Paulo, Departamento de Zoologia, Secretaria da Agricultura, p. 1-4. 
Papavero, N. 1977. The World Oestridae (Diptera), mammals and continental drift. The Hague, W. Junk Publishers. 248p.

Papavero, N. \& Guimarães, J. H. 2008. Catalogue of Neotropical Diptera. Cuterebridae. Neotropical Diptera 12:1-17.

PAPE, T. 2001. Phylogeny of Oestridae (Insecta: Diptera). Systematic Entomology 26:133-171.

Pape, T. 2010. Oestridae. In: Brown, B. V.; Borkent, A.; Cumming, J. M.; Wood, D. M.; Woodley, N. E. \& Zumbado, M. A. eds. Manual of Central American Diptera. v. 2. Boca Raton, NCR Research Press, p.1305-1311.

SChiner, J. R. 1868. Diptera. In: Wüllerstorf, U. ed. Reise der österreichischen Fregatte Novara um die Erde in den Jahren
1857, 1858, 1859, unter den Befehlen des Commodore B. von Wullerstorf-Urbair. Zoologischer Theil. v.2, Part 1, Section B. Wien, Hof- und Staatsdruckerei, p. 1-388.

SinClair, B. J. \& MCAlPINE, D. K. 1995. Zinza, a new genus of rhinotorine flies from northern Queensland, Australia (Diptera: Heleomyzidae). Records of the Australian Museum 47(3):225-230.

Steyskal, G. C. 1968. Family Neriidae. In: PAPavero, N. ed. A Catalogue of Diptera of the Americas South of the United States. São Paulo, Departamento de Zoologia, Secretaria da Agricultura, 49:1-7.

WiEDEmann, C. R. W. 1830. Aussereuropäische zweiflügelige Insekten. Als Fortsetzung des Meigenschen Werkes. Hamm, Zweiter Theil, Schulz. 684p. 